HNF-6920

Revision 0

\title{
Unvented Drum Handling Plan
}

Prepared for the U.S. Department of Energy

Assistant Secretary for Environmental Management

Project Hanford Management Contractor for the

U.S. Department of Energy under Contract DE-AC06-96RL13200

Fluor Hanford

P.0. Box 1000

Richland, Washington 


\section{INFORMATION CLEARANCE FORM}

\begin{tabular}{ll}
\multicolumn{2}{c}{ A. Information Category } \\
$\square$ Abstract & $\square$ Journal Article \\
$\square$ Summary & $\square$ Internet \\
$\square$ Visual Aid & $\square$ Software \\
$\square$ Full Paper & $\square$ Report \\
$\square$ Other &
\end{tabular}

\begin{tabular}{l} 
B. Document Number HNF- 6920 \\
\hline C. Title \\
Unvented Drum Handling Plan \\
\hline D. Internet Address
\end{tabular}

E. Required Information

1. Is document potentially Classified? $\square$ No $\square$ Yes (MANDATORY)

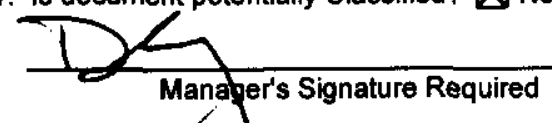

If Yes ADC signature Required

2. Internal Review Required? If Yes, Document Signatures Below

Counsel

Program

3. References in the Information are Applied Technology $\bigotimes_{\text {No }} \square$ Yes Export Controlled Information $\triangle$ No $\square$ Yes
4. Does Information Contain the Following: (MANDATORY)
a. New or Novel (Patentable) Subject Matter? $\square$ No $\square$ Yes

If "Yes", Disclosure No.:

b. Information Received in Confidence, Such as Proprietary and/or Inventions?

$\bigotimes$ No $\square$ Yes if "Yes", Affix Appropriate Legends/Notices.

c. Copyrights? $\square$ No $\square$ Yes If "Yes", Attach Permission.

d. Trademarks? $\square$ No $\bigotimes$ Yes If "Yes", Identify in Document.

5. Is information requiring submission to OSTI? $\quad$ No $\square$ Yes

If Yes UCand $B \& R-$

6. Release Level? $\bigotimes$ Public $\square$ Limited

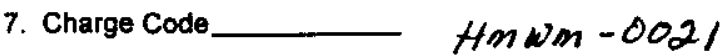

\section{F. Complete for a Journal Article}

1. Title of Journal

G. Complete for a Presentation

1. Title for Conference or Meeting

2. Group Sponsoring

3. Date of Conference

5. Will Information be Published in Proceedings? $\square$ No $\square$ Yes

4. City/State

H. Author/Requestor

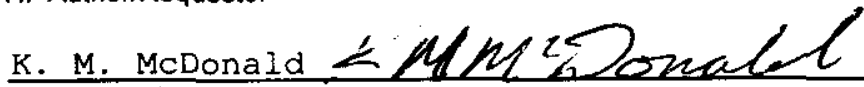
(Print and Sign)

I. Reviewers

Yes Print

General Counsel

If K. Norris

Office of External Affairs

DOE-RL

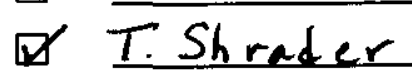

6. Will Material be Handed Out? $\square$ No $\square$ Yes

Other

$\square$

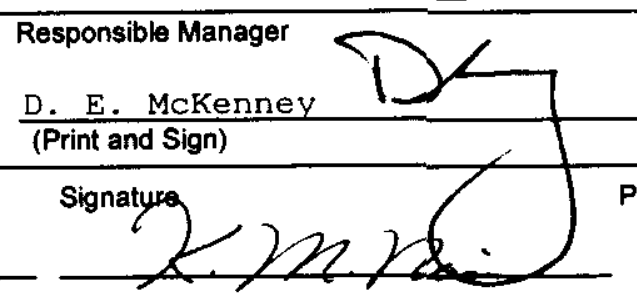

Public Y/N (If $\mathrm{N}$, complete J)

Other

J. If Information includes Sensitive Information and is not to be released to the Public indicate category below.
$\square$ Applied Technology
$\square$ Protected CRADA
$\square$ Personal/Private
$\square$ Export Controlled
$\square$ Proprietary
$\square$ Procurement-Sensitive
$\square$ Business-Sensitive
$\square$ Patentable
$\square$ Predecisional
$\square$ Other (Specify)
$\square$ UCNI

K. If Additionat Comments, Please Attach Separate Sheet

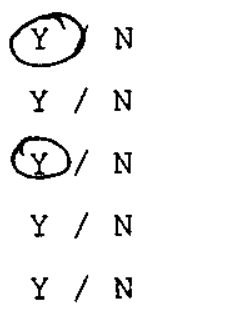

Information Clearance Approval

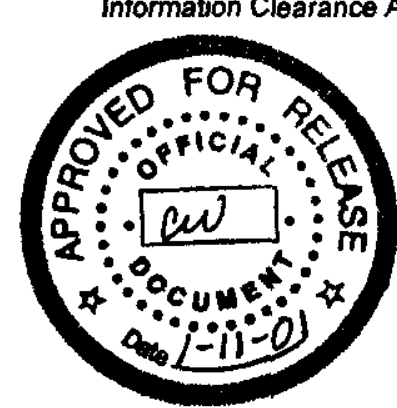


HNF-6920

Revision 0

\section{Unvented Drum Handling Plan}

Date Published

September 2000

Prepared for the U.S. Department of Energy

Assistant Secretary for Environmental Management

Project Hanford Management Contractor for the

U.S. Department of Energy under Contract DE-AC06-96RL13200

Fluor Hanford

P.0. Box 1000

Richland, Washington

$\frac{\text { Ahrestine Mhllexgesend } 1-11-01}{\text { Release Approval }}$ 
LEGAL DISCLAIMER

This report was prepared as an account of work sponsored by an agency of the United States Government. Neither the

United States Government nor any agency thereof, nor any of their employees, nor any of their contractors, subcontractors or their employees, makes any warranty, express or implied, or assumes any legal liability or responsibility for the accuracy, completeness, or any third party's use or the results of such use of any information, apparatus, product, or process

disclosed, or represents that its use would not infringe privately owned rights. Reference herein to any specific commercial product, process, or service by trade name, trademark, manufacturer, or otherwise, does not necessarily constitute or imply its endorsement, recommendation, or favoring by the United States Government or any agency thereof or its contractors or subcontractors. The views and opinions of authors expressed herein do not necessarily state or reflect those of the United States Government or any agency thereof.

This report has been reproduced from the best available copy. 
HNF-6920

HNF-6920

Revision 0

\section{UNVENTED DRUM HANDLING PLAN}

Prepared by:

K. M. McDonald

D. C. DeRosa

Fluor Hanford

August 2000

Prepared for the U.S. Department of Energy 


\section{EXECUTIVE SUMMARY}

During FY 2000 TRU retrieval activities, it was discovered that two shipments of Sequoia Fuels TRU waste drums did not have appropriate venting devices to prevent the buildup of hydrogen gas, revealing a condition that was insufficiently evaluated in the Authorization Basis. Although it was expected that TRU retrieval activities would eventually encounter unvented drums, it was not expected that this would occur until retrieval of covered drums began using a future Authorization Basis revision to allow excavation and venting of the drums. This plan presents the path forward for managing of unvented drums, and shows the controls that will allow for safe handling and venting of any unvented drums encountered in the future.

Although not all of the drums from these two shipments have been inspected, they contain a total of $76 \mathrm{TRU}$ waste drums that potentially do not have venting devices or recombiner packs. The drums were placed in the Low-Level Burial Grounds in 1985, which is consistent with the Authorization Basis assumption. However, the drums were authorized for acceptance under a previous version of acceptance criteria that did not require venting devices. This represents a discovery that the frequency of unvented drums in the exposed inventory is higher than assumed in the Low-Level Burial Grounds authorization basis. A Justification for Continued Operations was written [Hanson, 2000] and subsequently approved [Klein, 2000] by DOE-RL to allow continued retrieval activities. The approval of the Justification for Continued Operations requires that the plan for dealing with unvented drums during retrieval be accelerated.

For TRU drums to be accepted into the Central Waste Complex, the drums must have a venting device installed. This plan evaluates the various options, including venting equipment and venting location, available to safely place a filter vent in the unvented drums. The options outlined in this plan consider hazards of a bulging and/or pressurized drum, venting necessity of low-level drums, and venting of TRU drums.

Based on the information contained herein, the recommended approach is to vent the unvented TRU drums in the Low-Level Burial Grounds using drum-venting equipment supplied by a commercial vendor. This will require a modification to the Low-Level Burial Grounds authorization basis and may require some air permitting. If funding for these activities can be obtained early in FY 2001, then venting of drums can begin late in FY 2001. If no funding can be identified in FY 2001, then the drum venting activity will be reprioritized in FY 2002 and venting activities can begin late in FY 2002.

Until such time as these preparations can be made, the unvented drums that have already been encountered, as well as any more that are encountered during retrieval of the remainder of the unburied drums, will remain in the Low-Level Burial Grounds, with appropriate controls in place. These controls include, but are not limited to, covering the drums to protect from direct solar exposure, minimization of container movement, and restricting vehicle access.

Proceeding with drum venting activities as described, and any necessary additional administrative controls, will be based on approval of the necessary safety analysis documentation, including Richland Operation Office approval of a revision to the authorization basis. 


\section{TABLE OF CONTENTS}

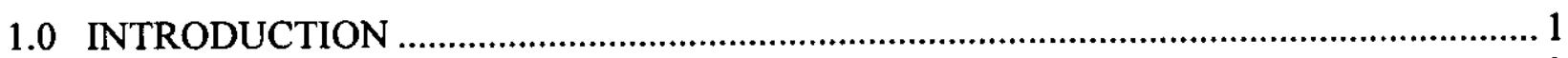

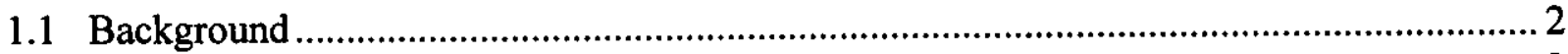

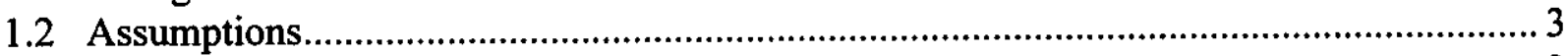

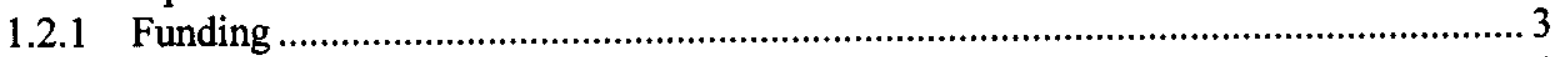

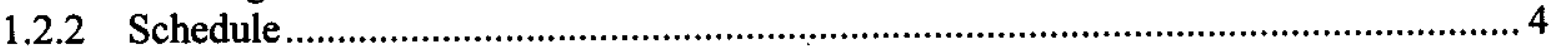

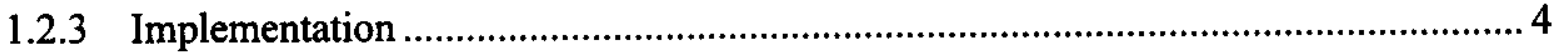

1.2.4 Unvented Drum Frequency ............................................................................... 4

1.2.5 Explosive Hydrogen Frequency ......................................................................... 4

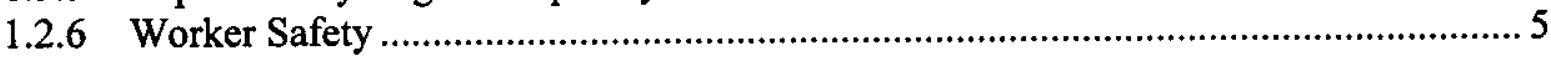

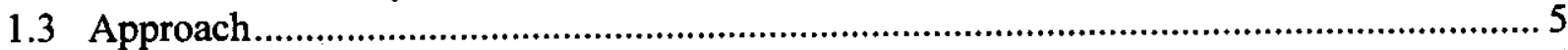

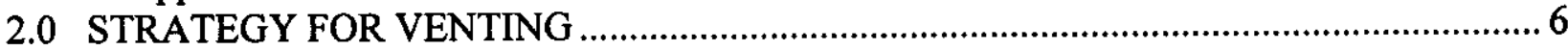

2.1 Visually Pressurized Containers .......................................................................................6

2.2 Drums with Low Plutonium Levels ................................................................................. 6

2.3 Drums with Higher Plutonium Levels ...........................................................................

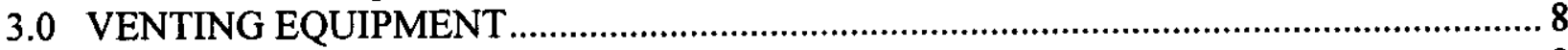

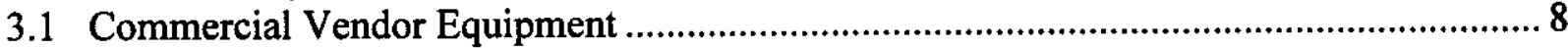

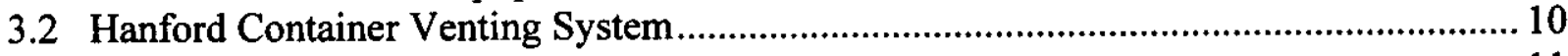

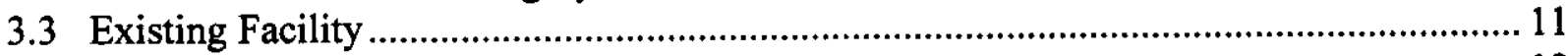

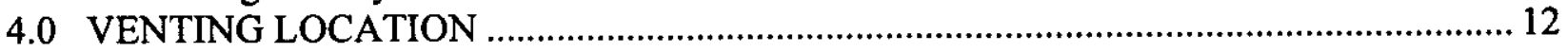

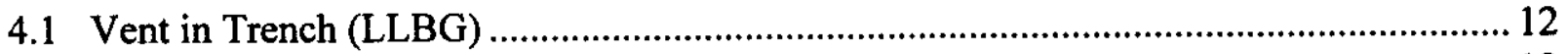

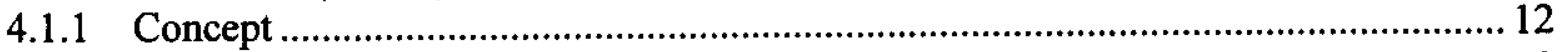

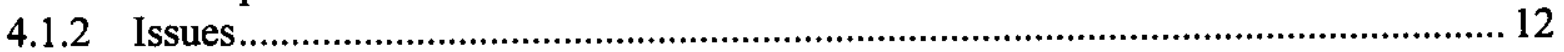

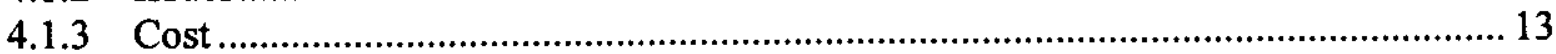

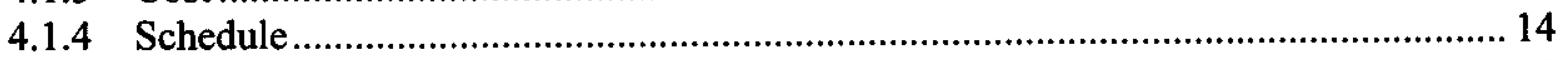

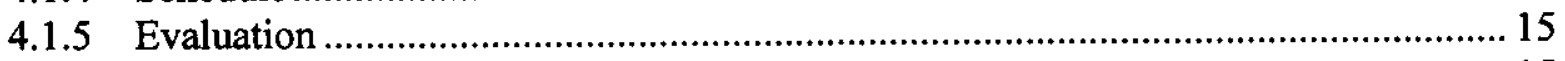

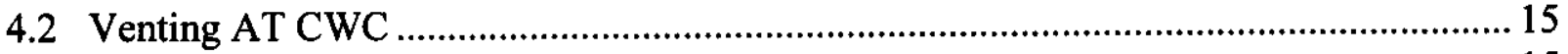

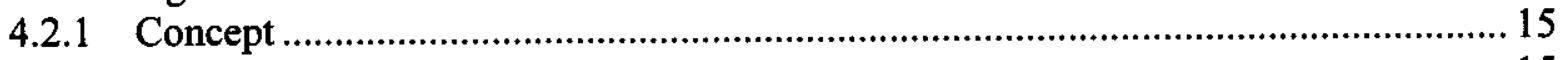

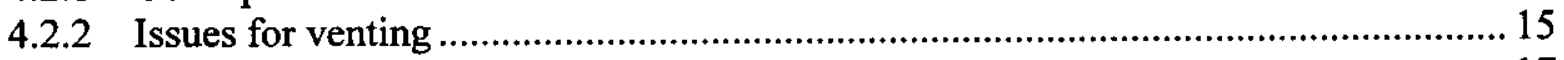

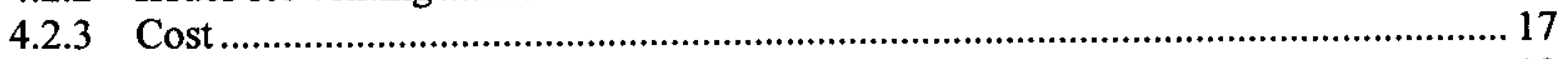

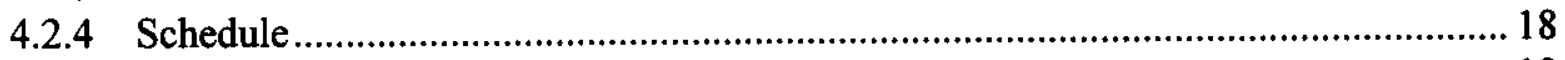

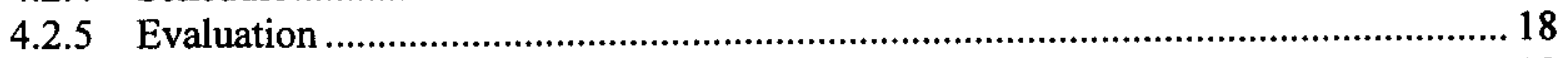

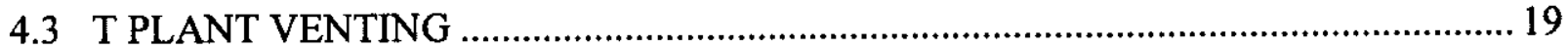

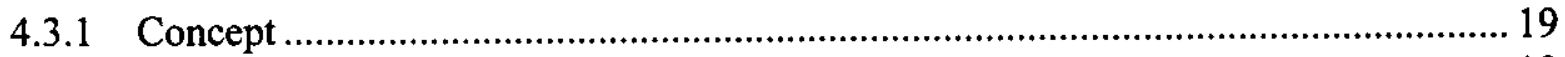

4.3.2 Issues for venting .......................................................................................... 19

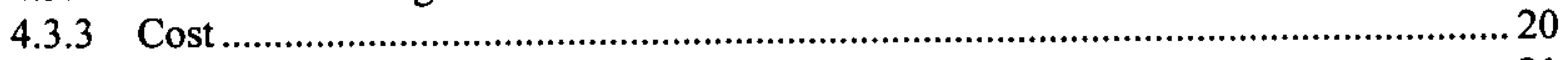

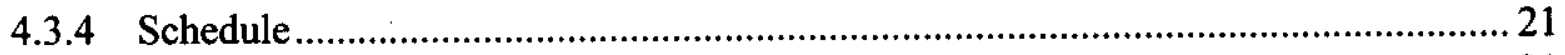

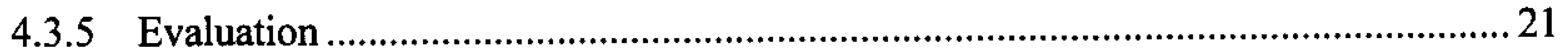

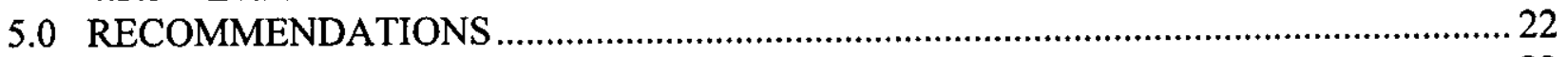

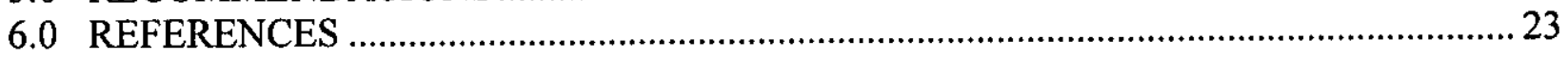




\section{$1.0 \quad$ INTRODUCTION}

This drum-handling plan proposes a method to deal with unvented transuranic drums encountered during retrieval of drums. Finding unvented drums during retrieval activities was expected, as identified in the Transuranic (TRU) Phase I Retrieval Plan (HNF-4781). However, significant numbers of unvented drums were not expected until excavation of buried drums began. This plan represents accelerated planning for management of unvented drums.

A plan is proposed that manages unvented drums differently based on three categories. The first category of drums is any that visually appear to be pressurized. These will be vented immediately, using either the Hanford Fire Department Hazardous Materials (Haz. Mat.) team, if such are encountered before the facilities' capabilities are established, or using internal capabilities, once established. To date, no drums have been retrieved that showed signs of pressurization. The second category consists of drums that contain a minimal amount of $\mathrm{Pu}$ isotopes. This minimal amount is typically less than 1 gram of Pu, but may be waste-stream dependent. Drums in this category are assayed to determine if they are low-level waste (LLW). LLW drums are typically disposed of without venting. Any unvented drums that assay as TRU will be staged for a future venting campaign, using appropriate safety precautions in their handling. The third category of drums is those for which records show larger amounts of $\mathrm{Pu}$ isotopes (typically greater than or equal to $1 \mathrm{gram}$ of $\mathrm{Pu}$ ). These are assumed to be TRU and are not assayed at this point, but are staged for a future venting campaign. Any of these drums that do not have a visible venting device will be staged awaiting venting, and will be managed under appropriate controls, including covering the drums to protect from direct solar exposure, minimizing of container movement, and placement of a barrier to restrict vehicle access.

There are a number of equipment options available to perform the venting. The preferred option is to use equipment provided by a commercial vendor during the first few years of retrieval and venting. This is based on a number of reasons. First, retrieval funding is uncertain. Using a commercial vendor will allow DOE-RL to avoid the investment and maintenance costs if retrieval is not funded. Second, when funding can be identified, retrieval will likely be performed with minimal initial throughput and intermittent operations. Again, costs can be saved by using contracted vendor services only as needed, rather than supporting Hanford equipment full time. When full-scale retrieval begins and the number of drums requiring venting increases significantly, then use of the Hanford container venting system (CVS) should be considered.

Given proper authorization, venting could be performed in several of the Solid Waste facilities at the Hanford site. Each facility has its own requirements and issues relative to performing the venting activity. In order to minimize the handling of unvented drums, the preferred option, as presented in this plan, is to vent the drums in the Low-Level Burial Grounds (LLBG).

During full-scale TRU retrieval activities, the frequency of unvented drums is assumed to approach 100 percent of the yearly campaign ( 2000 drums). This quantity of unvented drums presents an unacceptable risk from an authorization basis perspective and mitigation of unvented drums is assumed to be required. This assumption is consistent with TRU drum retrieval 
activities at Savannah River Site (SRS) and Los Alamos National Laboratory. Both of these sites deployed a drum venting system that vented and filtered the retrieved drums prior to placing them in above- ground storage.

\subsection{Background}

The Hanford Site is one of ten U. S. Department of Energy (DOE) sites that generate and/or store TRU wastes generated by national defense programs. In 1970, the U. S. Atomic Energy Commission defined TRU waste as a separate waste category and declared that it must be stored in a form that is retrievable as contamination-free packages designed to last 20 years, pending decisions on permanent disposal (AEC 1970). Since 1970, approximately 37,400 suspect-TRU and/or TRU waste containers have been placed in retrievable storage at the Hanford Site.

When TRU waste retrievable storage began in 1970, the TRU waste definition was any "waste with known or detectable contamination of transuranium radionuclides" (AEC 1970). In 1973, the limit for TRU was specified as 10 nanocuries of alpha-emitting transuranic isotopes per gram of waste $(\mathrm{nCi} / \mathrm{g})$, and, in 1982 , the limit was revised upward to $100 \mathrm{nCi} / \mathrm{g}$. Because of the changes in the definition of TRU waste as well as the methods by which waste was determined to be TRU, some fraction of the waste initially disposed of as TRU will be LLW under current definitions.

In 1976, hydrogen generation in waste containers was recognized as a potential problem throughout the DOE Complex. Initially, a recombiner pack was placed in the drums to recombine the hydrogen gas with oxygen. Hanford added an additional device, the Hanforddeveloped vent clip that was inserted between the lip of the drum and the sealing gasket. This vent clip would allow the release of hydrogen gas.

Prior to 1985 , generators of TRU waste were not required to install recombiner packs or vent clips. Prior to this, the storage and disposal facility accepting the waste would perform a review and determine if hydrogen mitigation devices were required. On-site large quantity generators of TRU voluntarily began installing recombiners and vent clips as early as 1978 . Off-site generators were slower to utilize venting devices due to difficulties in meeting transportation requirements with the vent clips installed.

In 1983, waste from Sequoia Fuels (Kerr McGee) was authorized per the requirements of RHOMA-222 that allowed an evaluation to be performed regarding the possibility of hydrogen gas generation. The transmittal letter to Sequoia Fuels did not indicate that venting of the waste was required or that a hydrogen generation problem existed. The waste was received in 1985 when it was a requirement that TRU waste drums have recombiners or be vented. The first two shipments of TRU waste from Sequoia Fuels did not have venting devices, and were emplaced in 218-W-4C, Trench 29.

In 1989, Nuclear Filter Technology (NFT) Corporation developed a filter/vent that can be installed in the drum lid to prevent a build up of pressure or hydrogen gas. This became the standard device for venting of TRU drums. This filter, or equivalent, is currently a requirement 
for acceptance of new containers at the Central Waste Complex (CWC). The Hanford vent clip is also an allowable venting device for acceptance of retrieved drums at the CWC.

In 1994, the LLBG Interim Safety Basis was approved. This provided the safety basis to address the exposed inventory of TRU waste. One of the accidents considered was an explosion of a TRU drum. The assumption to control the explosion was that all unburied TRU drums were required to have venting devices such as a vent clip. At the time of container placement in the trench, it was required that drums be vented. The frequency that drums would not be vented was assumed to be 1 in 1000 drums, and human error (failure to install the vent clip) was assumed to be the reason the drums were not vented. It was recognized that covered (buried) drums were not vented, and the authorization basis $(A B)$ specifically requires additional analysis of the methods planned for handling these drums.

During FY 2000 TRU relocation activities, it was discovered that drums from two shipments of Sequoia Fuels drums did not have vent clips and created a condition that was not evaluated in the $\mathrm{AB}$. Although not all of the drums from these shipments have been inspected, there were a total of 76 drums that may not have venting devices. This has led to a discovery that the frequency of unvented drums in the exposed inventory is higher than assumed in the DOE approved $\mathrm{AB}$. $\mathrm{A}$ Justification for Continued Operations was written [Hansen, 2000] and subsequently approved [Klein, 2000] to allow continued operation of the LLBG TRU retrieval trenches.

For TRU drums to be accepted into CWC, the drums must have a filter or venting device installed. This plan will evaluate the various options available to safely place a NucFil ${ }^{\circledR}$ filter vent or equivalent in the drums. The options outlined in this plan consider eminent hazards of a bulging and or pressurized drum, venting necessity of low-level drums, and venting of TRU drums.

\subsection{Assumptions}

This section lists some assumptions that are applicable to the unvented drum handling process.

\subsubsection{Funding}

Funding authorization will be pursued through formal change request. If funding for these activities can be obtained early in FY 2001, then venting of drums can begin late in FY 2001. If no funding can be identified in FY 2001, then the drum venting activity will be reprioritized in FY 2002 and venting activities can begin late in FY 2002. This reprioritization is based on the assumption that more unvented drums are accumulated during FY 2001 uncovered drum retrieval. The funding identified within this plan is intended to be rough order of magnitude costs. Where required by contract, a firm cost estimate will be prepared.

\footnotetext{
- NucFil is a registered trademark of Nuclear Filter Technology, Inc., Golden, CO.
} 


\subsubsection{Schedule}

For planning purposes, activities will show a scheduled start date of October 1, 2000. If funding is not available at that time, the end date will be adjusted to reflect the actual start date. The durations identified within this plan are not resource loaded, and the plan assumes that resources are available at the times outlined.

\subsubsection{Implementation}

The selected short-term alternative and long-term alternative will be implemented as funding and resources are dedicated to the process. This plan is not intended to provide sole authorization of drum venting alternative implementation. Proper $\mathrm{AB}$ documentation will need to be prepared and approved prior to implementation.

\subsubsection{Unvented Drum Frequency}

Presently, the unvented drum inventory in the unburied drums of $218-\mathrm{W}-4 \mathrm{C}$ is approximately 80 drums. The drums are mostly from the Sequoia Fuels cleanout campaign and the drums contain cut-up glove boxes. These drums were received in the 1985 time frame when drum-venting devices were beginning to be required for waste acceptance. There are 3 potentially unvented drums within this burial ground that are from the Plutonium Finishing Plant (PFP). The records for these drums show they were packaged with a vent clip and a recombiner pack, however, no vent clip is visible. The records indicate that these unvented drums have a low fissile inventory and therefore have a low potential for hydrogen generation.

For the remainder of the unburied drums, a record search of the drums in Trench 29 shows that there are no more instances of drums that were approved before the venting requirement, but shipped after (as the two Sequoia Fuels shipments). A similar record search will need to be performed for uncovered drums in Trench 1 and Trench 20 before retrieval efforts begin in those trenches. This information will be used during planning of retrieval activities in these trenches to assure worker safety in drum handling.

During retrieval of buried drums, it is anticipated that a much higher frequency of unvented drums will be encountered, typically in large groups. It was a common practice to place large batches of drums in the trench at one time as cleanout campaigns were conducted.

\subsubsection{Explosive Hydrogen Frequency}

A review was completed of the basis for assumption in the LLBG ISB that explosive concentrations of hydrogen are reached in unvented drums with a frequency of $4.6 \mathrm{E}-3$. The frequency is derived from an Idaho National Engineering Laboratory (INEL) study (EG\&G 1987). The numbers used in the ISB state that out of 184 drums from INEL and 33 drums from 
LANL (total of 217 drums) there was one drum that had an explosive mixture. "Explosive" is identified in the ISB as having $>18.3 \%$ and $<59 \%$ Hydrogen in air.

The study actually identifies $210 \mathrm{INEL}$ drums and 41 LANL drums. Seven drums with semipermeably gaskets can be eliminated, reducing the population from a total of 251 down to 244 drums. The selection criteria that were used to reduce the drums from the study down to the 217 drums in the ISB could not be readily identified. Using 244 drums instead of the 217 drums would result in a frequency of $4.1 \mathrm{E}-3$, thus the number used in the ISB is considered conservative.

It is understood that retrieval activities at Los Alamos may have resulted in additional data on hydrogen concentrations in TRU waste drums. Efforts are underway to obtain these data, if available. When received, these data will be evaluated against the assumptions in the LLBG ISB.

\subsubsection{Worker Safety}

A primary concern with any TRU retrieval activity, as with any activity at the Hanford Site, is worker safety. The LLBG ISB/JCO does not provide a complete analysis of worker safety issues relative to handling of unvented drums. The analysis contained in these documents is concerned more with public safety and releases to the environment. Worker safety is governed by a facility Health and Safety Plan. Plant operating procedures are used to guide the retrieval activities. To supplement these, additional analysis on job specific tasks is provided using the Automated Job Hazards Analysis (AJHA) process.

Safety analysis and job-specific procedures that are developed to allow venting of unvented TRU drums will need to look at worker safety issues and evaluate hazards relative to potentially pressurized and potentially explosive drums. Precautions will be taken during all handling and processing step to ensure that workers are adequately protected from hazards.

\subsection{Approach}

This plan presents various options for venting the unvented drums. 'These options are qualitatively evaluated based upon the following criteria:

1. Minimization unvented drum handling to ensure worker safety

2. Life-cycle cost effectiveness while controlling associated risks

3. Minimization of newly-generated waste

4. Minimization of transport of unvented drums

5. Schedule to begin venting activities

6. Protect the environment.

A detailed risk analysis of the various options was not performed. This will be performed, as needed, during development of the safety analysis and authorization documentation.

Costs estimates for the various options have not been performed in any detail. Cost estimates given are typically "best engineering judgment" unless a specific reference is given. 


\subsection{STRATEGY FOR VENTING}

This section identifies three scenarios for unvented drums. Each drum category can have a potentially different path for venting alternatives. Regardless of the category, precautions will be taken during all drum handling and processing steps to assure that workers are protected from explosion hazards.

\subsection{Visually Pressurized Containers}

Currently, if a container shows signs of being pressurized, the response is to contact the Hanford Fire Department and request the Haz. Mat. team to vent the container, regardless of where the container is located or whether it has a venting device. None of the unvented drums discovered as part of FY 2000 retrieval activities show visual signs of pressurization.

During full-scale retrieval, pressurized containers are not unexpected. The venting devices that are planned for full-scale retrieval include an enclosure that would contain a deflagration of a drum. These enclosure devices could also be used to vent pressurized containers at the direction of operations management if supported by approved safety analysis and authorization. The option still remains to notify the Hanford Fire Department and request the Haz. Mat. team to vent the container.

\subsection{Drums with Low Plutonium Levels}

Newly-generated TRU drums require venting per DOE order 435.1. Low-level drums do not typically require venting devices. The planning for TRU retrieval is that low-level drums will not be vented unless they exhibit visual indications of pressurization, or their contents inventory indicates a reason to suspect gas generation potential. Once a drum is designated as low-level waste, it will be transferred into a trench and disposed of.

Many drums with low plutonium levels will assay as LLW. During previous campaigns, about $50 \%$ of drums for which the records showed an inventory of 1 gram or less of plutonium were assayed as low-level waste. The $1 \mathrm{gram}$ level is based on experience to date, and may be revised with future experience. The present methodology of drum designation is to assay the drums in this category and determine if they are low-level or TRU prior to venting the drums. After further review, this methodology will continue to be used.

If an unvented drum in this category assays as TRU, then the drum will be set aside for venting. The interim actions for these drums will be to protect them from direct sun exposure, minimize container movement, and restrict vehicle access. Once a sufficient quantity of drums is assembled (typically 50), and the proper documentation is in place (safety basis, permits, etc.), a venting campaign will be performed. 
HNF-6920

\subsection{Drums with Higher Plutonium Levels}

These drums will be handled similar to drums containing less than 1 gram of plutonium; however, an assay will not be performed to confirm the radionuclide content (i.e., they are assumed to be TRU). The interim actions for any unvented drums in this category will be to protect them from direct sun exposure, minimize container movement, and restrict vehicle access. Once a sufficient quantity of drums is assembled (typically 50 ), and the proper documentation is in place (safety basis, permits, etc.), a venting campaign will be performed. 
HNF-6920

\subsection{VENTING EQUIPMENT}

There are three equipment system options available that are capable of venting TRU drums. These options are to contract the equipment and services of a commercial vendor, to activate the container venting system (CVS) that is in storage, or to utilize existing T Plant venting equipment. Although there are differences in design, each option is capable of performing the necessary functions. The preferred option, contracting of a commercial vendor, is based on a number of reasons. First, retrieval funding is uncertain. Using a commercial vendor will allow DOE-RL to avoid the investment and maintenance costs if retrieval is not funded. Second, when funding can be identified, retrieval will likely be performed with minimal initial throughput and intermittent operations. Again, costs can be saved by using contracted vendor services only as needed, rather than supporting Hanford equipment full time. It is not based on any physical weakness in any of the other systems. For this reason, if the commercial option becomes unviable for any reason, the option to activate the CVS or to ship unvented drums to T Plant could also be considered.

\subsection{Commercial Vendor Equipment}

One example of commercially available drum venting equipment is the Nuclear Filter Technology (NFT) system currently being used to vent TRU drums at the SRS. The NFT system is presented here for comparison to the Hanford options. Other commercial options may also be available.

NFT has developed a TRU drum venting and purging system, available through Mobile Characterization Services, the contractor that is performing drum assay for Hanford's current retrieval efforts. This equipment is presently deployed at the SRS under contract (Figure 1) and has been in use since March 1996. SRS contracted with NFT to design, build and operate the Drum Venting System (DVS). The DVS is capable of analyzing the drum head space with an on-line gas chromatograph (GC). The GC is programmed to sample for volatile organic compounds (VOC's), methane, and hydrogen. At SRS, the upper allowable limits for the gases are; $5.3 \%$ for VOC's, $1.1 \%$ for methane and $4.0 \%$ for hydrogen. If the gas sample is higher than the allowable limits, the drum is purged with nitrogen. Purging takes about 7 minutes, and the drum is resampled.

The DVS has three main components; a drum containment cabinet, a glovebox assembly, and an air filtration and handling train. The drum containment cabinet is a housing where the drum is located during the drilling and venting activities. This cabinet is designed to withstand a drum deflagration incident. The glovebox rests atop the drum containment cabinet, and provides a safe environment for the semi-remote performance of drum venting activities. The air filtration and handling train is used to provide airflow through the DVS (containment cabinet and glovebox). The air being removed from the enclosures is filtered through a roughing filter and two HEPA filters in series. The entire DVS system is modular and skid mounted. 
FIGURE 1

Drum Venting System Deployed at Savannah River Site

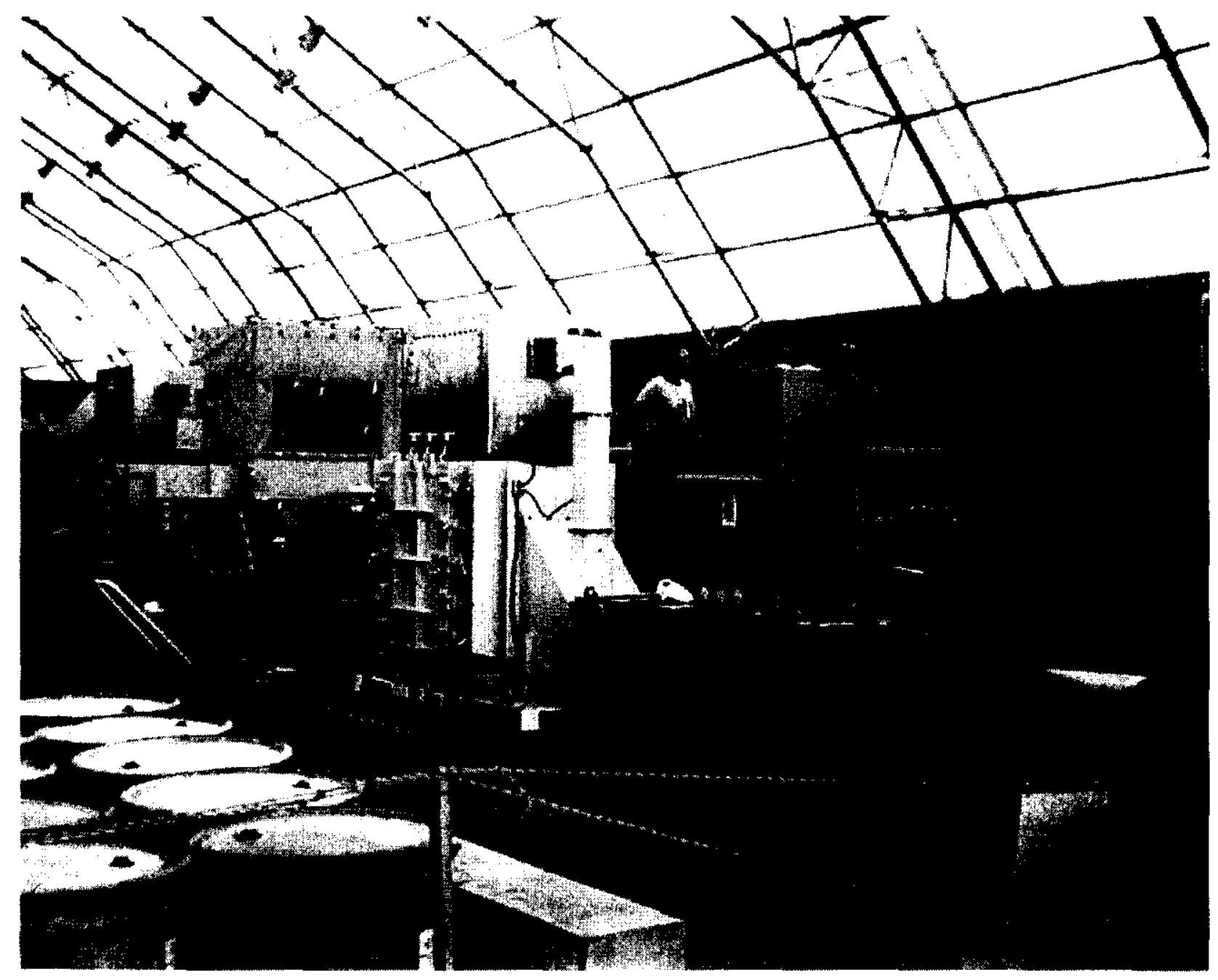

The filter assembly that is inserted into the drum is basically the NucFil ${ }^{\circledR}$ filter welded to a short hollow shaft, with a short drill bit welded to the bottom of the shaft. There are three small holes in the shaft. Two of the holes are for pulling gas samples from the drum headspace, and the third hole is used to purge the drum with nitrogen, if required.

The DVS is capable of venting 8 drums per day. All operations are controlled by a sequenced touch-screen linked to the programmable computer. Operation starts with the unvented drum being set on the drum roller dolly by the forklift operator. The door to the vent/purge chamber is opened and the platform is rolled into the chamber. The drum is positioned in the chamber and the door sealed. The drum is then elevated by an air bladder to the top of the vent/purge chamber. The drum is weighed during the lifting process, and must weigh less than 1,200 pounds. The drill assembly, holding the drill/filter device, is then lowered from its storage position in the small glovebox atop the vent/purge chamber and stops on the drum lid as the drill 
bit touches the drum lid. A neoprene donut at the bottom of the drill assembly contacts the drum lid and forms a seal around the drill assembly. The vacuum chamber is evacuated to 4 psia (about 200 Torr). The drill sequence is then initiated and the drill/filter assembly is drilled through the drum lid. The drill assembly drills intermittently so heat generation will be limited during the drilling process. Metal filings from drilling are removed so as not to interfere with the seal of the vacuum system.

\subsection{Hanford Container Venting System}

The Hanford Container Venting System (CVS) (Figure 2) that is presently in storage is also evaluated for use. The self-contained CVS is mobile (can be moved on a truck) from site to site and is remotely operated from a console for worker safety.

The CVS attaches and seals to the top and drills through the drum lid, draws a drum gas sample through a vacuum chamber into gas sample bottles and is capable of handling a drum weighing up to 3,000 pounds. The drilling of the hole in the container lid is done with a spark resistant titanium nitride drill bit. The drum can also be backfilled with an inert gas following venting. A $\mathrm{NucFil}^{\otimes}$ filter or equivalent will then be manually installed. While attached to the drum, the CVS is sealed to the drum such that any emissions are released through the HEPA-filtered exhaust.

The system consists of three components:

- The drum piercing assembly, which weighs approximately 440 pounds and is lifted atop a drum for venting.

- The control console, which operates the drum piercing, evacuation, gas sampling, backcharging of the drum with inert gas, and the attachment and detachment of the drum.

- The drum piercing enclosure (optional), in which the drum is placed to be pierced.

The system operation is sequentially controlled through fail-safe, go-no-go console switching. Flashing switch lights on the console direct the operator to the next step of the operation. The operator initiates the next process step by pushing the flashing switch. After completion of the process step, the light on the switch remains lit and the next lighted switch in the sequence flashes. A small programmable onboard computer controls the operation sequence. 
FIGURE 2

Hanford Container Venting System

\section{Container Venting and Gas Sampling System}

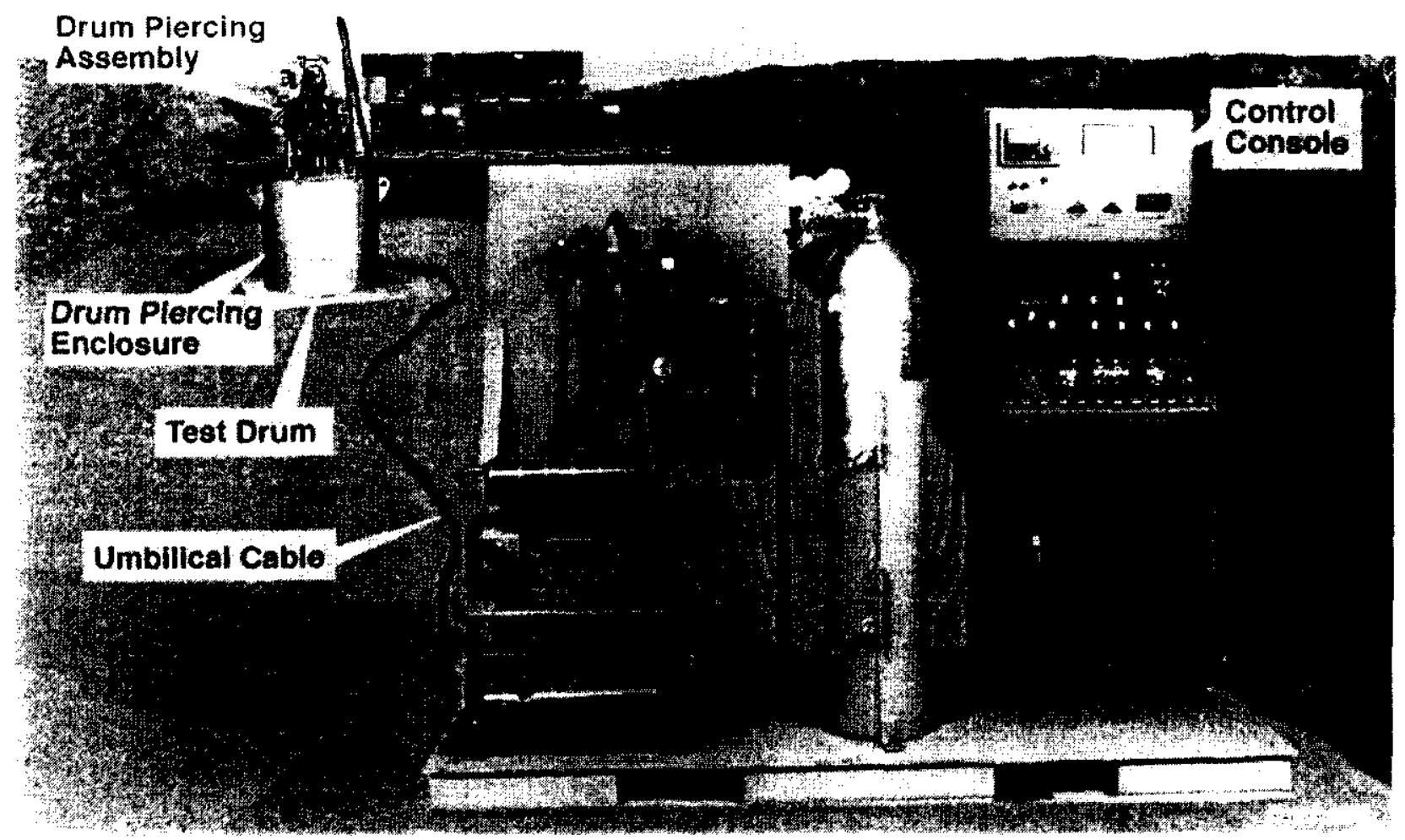

\subsection{Existing Facility}

The Solid Waste Treatment Facility (T Plant) routinely vents and opens potentially pressurized containers. The equipment that is used to accomplish this is a drum lid restraining device and a brone punch. T Plant has an active greenhouse with a IHIPA filtered exhaust system set up to perlorm this activity.

The drums are placed in the greenhouse and the greenhouse differential pressure established. The drum lid restraining device is secured around the drum the drum is grounded to prevent static shock, and a remote drum puncturing device is plaeed over the drum lid. Onee the piercing device is in place, the work area is cleared and the drum is punctured remotely. Prior to handling the drum again. the drum is surveyed by industrial hygiene and radiological control to determine comtamination levels. The detaikd steps for performing this activity are contained in existing Treatment racility operating Procedures. 


\section{0}

\section{VENTING LOCATION}

This section presents three possible venting locations; venting at the retrieval trench (in the LLBG), venting at $\mathrm{CWC}$, or venting at $\mathrm{T}$ Plant.

\subsection{Vent in Trench (LLBG)}

\subsubsection{Concept}

Drums would be vented in the retrieval trench using a commercial system or the Hanford CVS. A structure would be procured for weather protection. The structure would need to be relocated easily to facilitate retrieval activities. The structure would have to also withstand significant winds. Transportation of unvented drums outside the LLBG would not be required, minimizing the handling of unvented TRU retrieval drums.

\subsubsection{Issues}

\subsubsection{Safety Analysis Report}

Plant Review Committee (PRC) review is required for venting activities to occur within the LLBG. The venting of unvented drums at the LLBG has not been evaluated in the current LLBG authorization basis (AB). The single drum explosion accident evaluation should bound the venting equipment operation, but the operation of venting equipment within the LLBG has not been analyzed. Because venting has not been evaluated in the existing safety basis, it is uncertain if any equipment important to safety would be designated as the result of the safety analysis.

In order for drum venting activities to be allowed within the LLBG, the evaluation of the activity would require DOE-RL approval.

Excavation of buried drums does involve an unreviewed safety question (USQ) requiring modifications to the LLBG AB. The LLBG Interim Safety Basis (ISB) currently states that "Retrieval of buried TRU waste beyond the vented drums as analyzed in WWHC-SD-WM-SAR058] will require approval of additional safety analyses that revise the Solid Waste Burial Ground authorization basis." In addition, the LLBG safety basis does not currently address container venting operations, and a safety analysis evaluating the venting operation and identifying any operational limitations will require approval by DOE prior to initiating this activity.

As planned in the Transuranic (TRU) Phase I Retrieval Plan (HNF-4781), a separate safety assessment will provide the safety basis for operation of the TRU excavation and drum venting activities. The safety assessment will be provided as an addendum to the LLBG safety authorization basis until it can be incorporated in the LLBG ISB or the Solid Waste Facilities 
Master Safety Analysis Report (HNF-SD-WM-MSAR-001) (upon approval). This safety assessment for excavation and venting will need to consider worker safety issues relative to handling of unvented drums.

\subsubsection{Air Permitting}

If a commercial vendor or the Hanford CVS is used, a radioactive air emissions Notice of Construction (NOC) may be required depending upon the potential for the activity to emit.

If the venting system is set up inside of a greenhouse, an existing Portable/Temporary Radioactive Air Emissions Unit (PTRAEU) NOC could possibly be used for this activity and would not need a separate approval from Washington Department of Health (WDOH).

If the self-tapping, self-drilling NucFil ${ }^{\infty}$-type filter is used, there is no potential for emissions during installation of the filter. A NOC would not be needed for this activity, regardless of where the activity was performed. Once the filter is installed, any potential emissions from the vented drum are covered under the existing vented container NOC.

\subsubsection{Training}

For contractor equipment brought onto the site, the contractor could train Hanford personnel to operate the equipment.

If the Hanford CVS is selected, operating procedures and a training program to teach operators to run the equipment will have to be developed.

\subsubsection{Cost}

Rough order of magnitude costs to prepare for venting in the LLBG are shown in Table 1 and described below.

Table 1. Estimated Costs for Venting in the LLBG

\begin{tabular}{|l|l|}
\hline Item & Estimated Cost \\
\hline SAR Development (LLBG Excavation and venting) & $\$ 375,000$ \\
\hline Air Permit & $\$ 50,000$ \\
\hline Training and Readiness (excavation and venting) & $\$ 250,000$ \\
\hline Venting (first 100 drums) & $\$ 100,000$ \\
\hline Total & $\$ \$ 800,000$ \\
\hline
\end{tabular}




\subsubsection{SAR Development}

Venting in the LLBG has the advantage of requiring modification to only one safety basis document. The safety basis for the LLBG will require modification prior to retrieval of buried drums. Including in this modification the analysis necessary to perform venting in the LLBG will be an incremental cost that is difficult to quantify at this time, but should be significantly less than modifying two documents (e.g., the LLBG AB to authorize excavation and a SARP to authorized transportation of unvented drums).

For venting activities to be allowed within the burial grounds, the cost for developing and approving the authorization basis document that will allow for both drum venting and excavation activities within the LLBG is approximately $\$ 365,000$.

\subsubsection{Air Permit/NOC}

If venting is performed within the burial grounds, air permitting may be required prior to performing covered drum retrieval. The cost for developing air permitting documentation for performing venting and excavation retrieval activities is approximately $\$ 75,000$.

If the self-tapping, self-drilling NucFil -type filter is used, there would be no potential for emissions during installation of the filter. A NOC would not be needed for this activity, regardless of where the activity was performed. Once the filter is installed, any potential emissions from the vented drum are covered under the existing vented container NOC.

\subsubsection{Training/Readiness}

Training and readiness activities for venting and excavation retrieval were estimated in HNF4781 to be approximately $\$ 250,000$.

\subsubsection{Venting Activities}

A rough order of magnitude cost for venting and sampling the drums is $\$ 1,000 /$ drum. This is based on discussions with a potential commercial vendor with a campaign of about 50 drums. Larger campaigns will reduce the per drum cost. The cost includes VOC and hydrogen measurements, although it has not yet been determined how much, if any, sampling will be required.

\subsubsection{Schedule}

Safety analysis and $\mathrm{AB}$ modification will require approximately 6-9 months from the time funding is identified. Venting operations can begin approximately nine months after safety analysis work begins. 


\subsubsection{Evaluation}

Venting drums in the burial grounds is the preferred option. This option minimizes the handling of unvented drums, thus reducing the hazard to the facility worker. It eliminates the complication of providing transportation analysis for unvented drums, and it reduces the impact and potential for newly-generated LLW. The major document that will require modification for this option is the LLBG AB. The LLBG AB modification to address excavation and handling of unvented drums was already planned and is being accelerated by the need to deal with unvented drums earlier than expected.

\subsection{Venting AT CWC}

\subsubsection{Concept}

Drums would be moved to CWC where they would be vented in a CWC building using a equipment provided by a commercial vendor or using the Hanford CVS. Venting drums at CWC would provide versatility to venting operations. This facility would not limit the venting activities to TRU retrieval drums. There are three structures that could be used to vent drums. The 2401-W building is a permanent metal structure that has been used and considered for a variety of solid waste storage activities. The other two structures (Figure 3) are the temporary sprung structures that were erected for equipment storage. Structures similar to these were originally considered for the weather enclosure on the original design of full-scale retrieval. Using either of these three structures for venting would provide the necessary protection from sunlight and would provide restricted vehicle access. The use of $\mathrm{CWC}$ for venting would require $\mathrm{AB}$ revisions to document the acceptability of safety and risks.

\subsubsection{Issues for venting}

\subsubsection{Transportation}

In order to ship the drums, an evaluation will be required for each container to determine the potential quantity of hydrogen. Factors within this calculation will need to include the waste matrix, proximity of hydrogenous material in relation to radiological source, void space, head space volume and concentration determination. If this calculation identifies that it is possible to create an explosive hydrogen concentration (greater than 4 percent), then special transportation issues will need to be addressed. However, if the calculation does not identify a greater than 4 percent hydrogen concentration, then an existing safety analysis report for packaging (SARP) can be modified to allow for the shipment of the drums. 
FIGURE 3

\section{Spring Structure at Central Waste Complex}

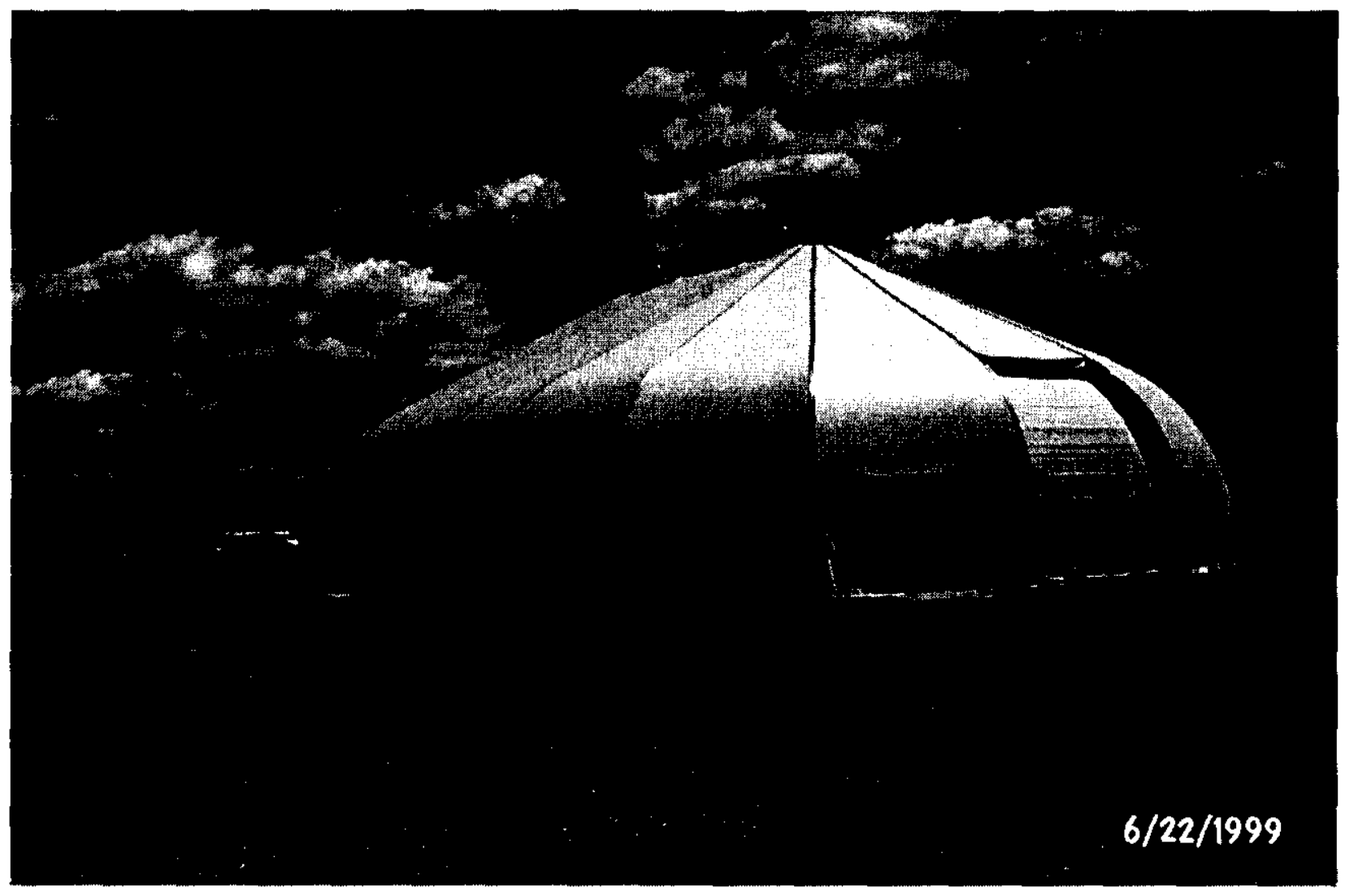

For hydrogen concentrations above 4 percent. a new SARP will be required to address the special conditions. This level of effort and risk will require the approval of DOE-RI.

As an alternative to developing a SARP to allow transport of these drums, the ( $W C A B$ can be revised to encompass the transport of these drums between and within the facilities. This level of eflort and risk will require the approval of I)OJ:-RI.

\subsubsection{Authorization Basis}

Pant Review Committee review is required for venting activities to occur within the CWC. The current ( WC $A B$ does not evaluate any type of drum venting, opening, or relidding. The single drum explosion accident evaluation should bound the CVS or similar operation. but the operation of the venting equipment within the CWC has not been analyzed. Because venting has not been evaluated in the existing safety basis, it is uncertain if any equipment important to salety would be designated as the result of the safety analysis.

DO) :-RI approval would be required to allow drum venting activities within the ('WC.' 


\subsubsection{Air Permitting}

If a commercial vendor or the Hanford CVS is used, a NOC may be required depending upon the potential for the activity to emit.

If the venting system is set up inside of a greenhouse, an existing Portable/Temporary Radioactive Air Emissions Unit (PTRAEU) NOC could possibly be used for this activity and would not need a separate approval from Washington Department of Health (WDOH).

If the self-tapping, self-drilling $\mathrm{NucFil}^{\circledR}$-type filter is used, there is no potential for emissions during installation of the filter. A NOC would not be needed for this activity, regardless of where the activity was performed. Once the filter is installed, any potential emissions from the vented drum are covered under the existing vented container NOC.

If using the CVS (or similar process), another option would be to set up the Permacon unit within a CWC building and vent the drums inside the Permacon. This activity would be covered by the existing NOC for the Permacon without a NOC revision and would not need separate WDOH approval.

\subsubsection{Training}

For contractor equipment brought onto the site, the contractor will train Hanford personnel to operate the equipment.

If the Hanford CVS is selected, operating procedures and a training program to teach operators to run the equipment will need to be developed.

\subsubsection{Cost}

Rough order of magnitude costs to prepare for venting in the CWC are shown in Table 2 and described below.

Table 2. Estimated Costs for Venting in the CWC

\begin{tabular}{|l|l|}
\hline Item & Estimated Cost \\
\hline SAR Development (LLBG Excavation) & $\$ 300,000$ \\
\hline SAR Development (Transportation and CWC Venting) & $\$ 175,000$ \\
\hline Air Permit & $\$ 50,000$ \\
\hline Training and Readiness (LLBG Excavation) & $\$ 250,000$ \\
\hline Training and Readiness (CWC Venting) & $\$ 50,000$ \\
\hline Venting (first 100 drums) & $\$ 100,000$ \\
\hline Total & $\mathbf{\$ 9 2 5 , 0 0 0}$ \\
\hline
\end{tabular}




\subsubsection{SAR Development}

For venting activities to be allowed within the $\mathrm{CWC}$, the cost for developing and approving the authorization basis document to allow for drum venting within the CWC is approximately $\$ 175,000$.

It should be noted that modification of the LLBG AB to allow for future excavation of suspect TRU drums would still be required (approximately $\$ 300,000$ ).

\subsubsection{Air Permit/NOC}

If venting is performed within the $\mathrm{CWC}$, air permitting may be required prior to performing covered drum retrieval. The cost for developing air permitting documentation for performing venting and retrieval activities is approximately $\$ 50,000$.

\subsubsection{Training/Readiness}

Training and readiness activities would only include venting activities. HNF-4781 estimated training and readiness costs to be approximately $\$ 250,000$, but this included excavation. It is estimated that training and readiness for venting only would cost about $\$ 50,000$. Training for excavation activities would still be required at some future date.

\subsubsection{Venting Activities}

A rough order of magnitude cost for venting and sampling the drums is $\$ 1,000 /$ drum. This is based on discussions with a potential commercial vendor with a campaign of about 50 drums. Larger campaigns will reduce the per drum cost. The cost includes VOC and hydrogen measurements, although it has not yet been determined how much, if any, sampling will be required.

\subsubsection{Schedule}

Safety analysis and AB modification or SARP modifications will require approximately 6-9 months from the time funding is identified. Venting operations can begin approximately nine months after safety analysis work begins.

\subsubsection{Evaluation}

Venting drums in the CWC is not the preferred option. This option does not minimize the handling of unvented drums. It necessitates that a transportation analysis be performed for unvented drums, and it may cause LLW to be newly-generated. Major documents that will 
require modification for this option are the CWC AB and a drum SARP. These are not currently planned. The LLBG AB modification to address excavation and handling of unvented drums will still be required.

\subsection{T PLANT VENTING}

\subsubsection{Concept}

Unvented drums would be moved to $T$ Plant where they would be vented using existing equipment. Presently, T Plant performs drum venting using the drum lid restraining device and the piercing system. This system does not allow for gas analysis. The monitoring that is performed is for worker safety and to limit personnel exposure to chemicals. An operating procedure is presently in place for venting drums.

\subsubsection{Issues for venting}

\subsubsection{Transportation}

In order to ship the drums, an evaluation will be required for each container to determine the potential quantity of hydrogen. Factors within this calculation will need to include the waste matrix, proximity of hydrogenous material in relation to radiological source, void space, head space and concentration determination. If this calculation identifies that it is possible to create an explosive hydrogen concentration (greater than 4 percent), then special transportation issues will need to be addressed. However, if the calculation does not identify a greater than 4 percent hydrogen concentration, then an existing SARP can be modified to allow for the shipment of the drums.

For hydrogen concentrations above 4 percent, a new SARP will be required to address the special conditions. This level of effort and risk will require the approval of DOE-RL.

As an alternative to developing a SARP to allow transport of these drums, the facility authorization basis can be revised to encompass the transfer of these drums within the facility. This level of effort and risk will require the approval of DOE-RL.

\subsubsection{Authorization Basis}

The drum venting activity is allowed and authorized in the Treatment Facility AB documents. The fissile inventory of drums to be vented is limited to 177 fissile gram equivalents (FGE). If a drum is over $177 \mathrm{FGE}$, it can not be vented at the Treatment facility without further evaluation. Also, there are other source strength limits that would severely limit the number of drums that could be staged at T Plant 


\subsubsection{Air Permit}

If the self-tapping, self-drilling NucFil ${ }^{\circledR}$-type filter is used, there would be no potential for emissions during installation of the filter. A NOC would not be needed for this activity, regardless of where the activity was performed. Once the filter is installed, any potential emissions from the vented drum are covered under the existing vented container NOC.

If this CVS venting activity is conducted at 2706-T, a NOC modification will need to be approved by WDOH since the original NOC for 2706-T (approved 6/12/96) does not include drum venting.

If the CVS (or similar process) is set up inside of a greenhouse, the PTRAEU NOC could be used for this activity and would not need a separate approval from WDOH. The primary requirements we would need to follow with the PTRAEU NOC are some record keeping requirements.

\subsubsection{Training}

The drum piercing equipment is operated using operating procedures, which meet the requirements of Hanford site documentation. This method of venting will not require any additional training at the Treatment Facility unless another venting system is used.

\subsubsection{Cost}

Rough order of magnitude costs to prepare for venting at T Plant are shown in Table 3 and described below.

Table 3. Estimated Costs for Venting at $T$ Plant

\begin{tabular}{|l|l|}
\hline Item & Estimated Cost \\
\hline SAR Development (LLBG Excavation) & $\$ 300,000$ \\
\hline SAR Development (Transportation to T Plant) & $\$ 150,000$ \\
\hline Air Permit & $\$ 0$ \\
\hline Training and Readiness (LLBG Excavation) & $\$ 250,000$ \\
\hline Training and Readiness (T Plant Venting) & $\$ 0$ \\
\hline Venting (first 100 drums) & $\$ 120,000$ \\
\hline Total & $\mathbf{\$ 8 2 0 , 0 0 0}$ \\
\hline
\end{tabular}

\subsubsection{SAR Development}

Venting activities for drums less than 177 FGE are already conducted based on the existing AB. A SARP would need to be developed to allow the shipment of the unvented drums. Based on experience with the TRU drum SARPs, the cost for this activity is estimated to be $\$ 150,000$. 
It should be noted that modification of the LLBG AB to allow for future excavation of suspect TRU drums would still be required (approximately $\$ 300,000$ ).

\subsubsection{Air Permit/NOC}

There will be no change to air permitting requirements to utilize the presently approved Operating Procedure to remove and replace the lids. Venting with other equipment may require air permitting.

\subsubsection{Training/Readiness}

Training and readiness activities would not be necessary if existing equipment is used. Training may be required if other equipment is used.

\subsubsection{Venting Activities}

A rough order of magnitude cost for venting drums at $\mathrm{T}$ Plant is $\$ 1,200 / \mathrm{drum}$. This is based on previous estimates prepared internally. The cost does not include quantitative gas sampling.

\subsubsection{Schedule}

SARP modifications will require approximately 6-9 months from the time funding is identified. Venting operations can begin approximately nine months after safety analysis work begins.

\subsubsection{Evaluation}

Venting drums at $T$ Plant is not the preferred option. This option does not minimize the handling of unvented drums. It necessitates that a transportation analysis be performed for unvented drums, and it may cause LLW to be newly-generated. The major document that will require modification for this option is the TRU drum SARP. This specific modification is not currently planned. The LLBG AB modification to address excavation and handling of unvented drums will still be required. 


\subsection{RECOMMENDATIONS}

It is recommended that unvented drums encountered in the LLBG during TRU retrieval activities be vented in the LLBG. This minimizes handling of the drums, eliminates the need for transportation of unvented drums, and minimizes the amount of newly-generated LLW. If also requires the least amount of paperwork changes, in this case to the LLBG AB, a change that was already planned. Other options require additional analysis or additional AB/SARP changes and do not minimize the handling of unvented drums.

For the first few years, while TRU retrieval is occurring intermittently throughout the year, and only a portion of the drums require venting, the venting will be performed using equipment provided by a commercial vendor. In this manner, it is economically feasible to vent drums in lots of about 50 or more. When TRU retrieval is occurring full scale, year round, or the majority of drums retrieved require venting, at that time it may be useful to reevaluate the venting equipment and explore the possibility of activating the Hanford CVS.

It is recommended that the approximately 80 unvented drums that have been identified in Trench 29 be vented as soon as proper safety analysis authorization and approval can be obtained and a contract placed with a commercial vendor.

It is recommended that drums that are visually observed to be pressurized be vented immediately. Pending further evaluation, drums with minimal Pu inventory (nominally less than 1 gram $\mathrm{Pu}$ ) will be assayed prior to venting. Drums assaying as LLW can typically be disposed of without venting. Unvented drums that assay as TRU will be staged to await a venting campaign. Unvented drums with a larger $\mathrm{Pu}$ inventory (typically greater than or equal to 1 gram $\mathrm{Pu}$ ) will be assumed to be TRU and will be staged to await a venting campaign. A venting campaign will typically be scheduled when there are about 50 or more drums ready to be vented. All drums staged awaiting venting will be maintained under appropriate controls, including covering the drums to protect from direct solar exposure, minimizing of container movement, and restricting vehicle access. 


\subsection{REFERENCES}

Atomic Energy Commission, Immediate Action Directive 051-21, Washington D.C., 1970.

EG\&G, Safety Analysis for the Stored Waste Examination Pilot Plant (SWEPP) at the Idaho National Engineering Laboratory, WM-PD-87-023, Rev. 1, EG\&G Idaho, Inc., Idaho Falls, Idaho, 1987.

Hanson, R. D., to K. A. Klein, CONTRACT NUMBER DE-AC06-96RL13200 -

JUSTIFICATION FOR CONTINUED OPERATION (ASSAY AND SHIPMENT OF TRU WASTE CONTAINERS IN 218-W-4C TRENCH 29), Letter Number FH-0003822, July 19, 2000.

HNF-4781, Transuranic (TRU) Waste Phase I Retrieval Plan, Fluor Daniel Hanford Company, Richland WA, August 1999.

HNF-SD-WM-002, Solid Waste Burial Grounds Interim Safety Basis, Waste Management Federal Services of Hanford, Inc., Richland Washington, 1998.

HNF-SD-WM-ISB-006, Interim Safety Basis Document for Solid Waste Facilities (T Plant), Waste Management Federal Services of Hanford, Richland, Washington, 1997.

HNF-SD-WM-ISB-007, Central Waste Complex Interim Safety Basis, Waste Management Federal Services of Hanford, Inc., Richland, Washington, 1998.

HNF-SD-WM-SARR-028, Solid Waste Burial Grounds Interim Safety Analysis, Waste Management Federal Services of Hanford, Inc., Richland Washington, 1998.

HNF-SD-WM-TSR-005, Central Waste Complex Interim Operations Safety Requirements, Waste Management Federal Services of Hanford, Inc., Richland, Washington, 1997.

Klein, K. A., to R. D. Hanson, CONTRACT NO. DE-AC06-96RL13200 - JUSTIFICATION FOR CONTINUED OPERATIONS (JCO) (ASSAY AND SHIPMENT OF TRANSURANIC [TRU] WASTE CONTAINERS IN 218-W-4C TRENCH 29), Letter Number 0003963 A, DOERL: 00-ABD-053, July 20, 2000. 